\title{
The Efforts to Improve the Quality of Education in North Tapanuli Regency
}

\author{
Dr. Oktober Tua Aritonang, M.Pd
}

\author{
IAKN Tarutung, Indonesia \\ otaritonang68@gmail.com
}

\begin{abstract}
This study aims to describe in detail the condition of the quality of education in North Tapanuli Regency which has not been in line with expectations, and at the same time provides solutions that can be done to improve it. This study applies mixed method, library method and field studywith direct observation and collect information in the field. Based on the analysis, it is known that the quality of education in North Tapanuli regency still needs improvement which includes some aspects namely quality of graduates, quality of the learning process, competence of educators, facilities and infrastructure, and aspects of management, so that the quality of education can be improved. Efforts that can be done to improve the quality of education are improving teacher competencies, completing facilities and infrastructure, strengthening School-Based Management (SBM) and Integrated Quality Management (Total Quality Management), revitalizing cooperation between schools and the community, and maximizing educationmonitor.
\end{abstract}

Keywords-efforts, improve, quality of education.

\section{INTRODUCTION}

The quality of education becomes one problems faced by the government in Indonesia.There are some elements regarding to the quality of education such as quality of teachers and education personnel (principals, supervisors), teaching curriculum, learning methods, teaching materials, learning facilities and infrastructure, and school management. These are interrelated in an effort to improve the quality of teaching and learning which culminates in improving the quality of education. The government has issued several regulations such as Law Number 20 of 2003 concerning on the National Education System, Government Regulation Number 19 of 2005 which was revised in Government Regulation No. 13 of 2015 concerning on National Education Standards, which accommodate the implementation of educationquality.Furthermore, to achieve quality education the Government through the Ministry of Education and Culture has determined the direction of policies and strategies contained in the 2015-2019
Strategic Plan namely by increasing: active roles of students in the classroom, parent / family roles, teacher performance and education staff, access and service quality Early Childhood Education and secondary education through a 12-year quality compulsory education program, strengthening the quality assurance of education services, curriculum rearrangement, relevance of vocational education to the needs of the world of work, strengthening a comprehensive education assessment system, and improving education management.

The quality of education is multi-dimensional which covers aspects of input, process and output (outputs and outcomes). Therefore, indicators and education quality standards are developed holistically starting from inputs, processes and outputs. The low quality can be seen from several indicators: student learning outcomes (knowledge, attitudes and skills), teacher quality and teaching and learning process, facilities and infrastructure, quality of supervision and management or effectiveness and efficiency (Pananrangi, 2017: 238-242).

Criticis $m$ about the quality of education in Indonesia is very much expressed by education experts, education researchers, and education observers. Panjaitan et al. (2014: 111) states that problems in the world of education include: low physical facilities and quality of teachers as well as low opportunities for equal distribution of quality education and the relevance of education to needs.Tilaar (2006: 5-6) argues that the deterioration of the quality of national education does not lie in the intelligence abilities of Indonesian students, but is due to uneven opportunities in obtaining good education in the children of this nation.In addition, the role of the LPTK in particular as an institution for recruiting teacher training is very important. Problems that occur related to the quality of education can be rooted in problems related to managerial quality of education leaders, limited funds, facilities and infrastructure, educational facilities, media, learning resources, school climate, educational environment, and support from parties related to education (Syaodih, 2006: 8). So me phenomena that occur related to the condition of education quality in North 
Tapanuli for example: the capacity of the number of students exceeding the standard quota in accordance with the study group (Regulation of Education Min istry No. 24 of 2007), the lack of completeness of learning infrastructure such as computer laboratory rooms, language, biology, physics and ingredients for example the inadequate quantity and quality of computers, the learning process that still seems teacher oreinted with expository learning style so that the balance of soft skills with hard skills has not been achieved, there are still teachers who lack the scientific approach with the application of Project Based Learning, Problem Based Learn ing, Cooperative Learning and Contextual Teaching Learning, including lack of mastering authentic assessment design.In addition, there was noise between certification teachers due to lack of teaching hours, so the learning climate was disrupted. Some of the teachers who had received the previous certification allowance were forced to no longer accept it just because the mandatory 24 hour load was not fulfilled any more. This is due to the increase in teachers transferred to the school only because of the teacher's request, not on the basis of the principle of equity.Under these conditions, it will certainly affect the implementation of the learning process. The concentration of teachers who had felt comfortable doing their work has become disturbed. The impact was also increasingly widespread because of the conflict between the teacher and the teacher in the same group of study fields, also between the teacher and the principal who were blamed for having passed the need for the newly transferred teacher to the school.From the explanations stated in the background, the formulation of research problems that will be focused as follows: 1) What is the condition of the quality of education in North Tapanuli Regency?,2) What obstacles are faced in improving the quality of education in North Tapanuli Regency?, 3) What efforts should be done to improve the quality of education in North Tapanuli regency? Then, the writer entitled "Efforts to Improve the Quality of Education in North Tapanuli Regency " as the focus of the study in this paper. The writer is very motivated to review this topic because he hopes to contribute ideas to improving the quality of education, especially in North Tapanuli regency.

\section{REVIEW OF RELATED LITERATURE}

\subsection{The Quality of Education}

According to Deming (in Usman, 2006: 410) quality is conformity with needs or suitability with needs. Relative quality is not an end, but as a tool that has been determined whether it has met the standards that have been set. The quality of education is multi-dimensional (holistic) covering aspects of input, process and output (outcomes). The declared quality is high if the students' academic and non-academic learning outcomes are high. Outcome was declared quality if graduates were quickly absorbed in the world of work, salaries were reasonable, all parties recognized the greatness of their graduates and were satisfied.Similarly, Crosby asserted (in Hadis and Nurhayati, 2010: 85) that quality is something that is standardized or hinted at (conformance to requirement). A product has a quality if it is in accordance with a predetermined standard, the quality standard includes raw materials, production processes, and finished products. Quality is a dynamic condition related to products, labor, processes and tasks and the environment that meets or exceeds customer expectations. With these quality changes, it is necessary to increase or change the skills of labor, production processes and tasks, as well as changes in the company's environment so that products can meet and exceed consumer expectations (Garvi and Davis, in Hadis and Nurhayati, 2010: 86). The quality of education is education that is able to produce graduates who have academic competencies and vocational competencies, which are based on personal and social competencies, as well as noble moral values, all of which are life skills. They are capable of integrating faith, knowledge and deeds (Sudaradjat, 2005: 17).So the authors conclude that, quality education is education that has dimensions / components namely input, process and output (results) that have met predetermined standards, and produce graduates with established skills (life skills), both in academic, vocational, personal social competence and having character values.

\subsection{The Characteristics ofEducation Quality}

Usman (2006: 411) suggests that there are several characteristics possessed by the quality of education, namely:a) Performance or performance which is related to the functional aspects of the school including: the teacher's performance in teaching, for example the skill in choosing the right strategy or method and media, b) Consistency, which is constancy, constant and stable, for example school quality does not decline from the past until now, school residents are consistent with the imple mentation of the existing rules, c) Timelines, that is, according to a reasonable time, including starting and ending the lesson on time, the exact time of repetition, d) Reliable (reliability), namely the long service life that includes excellent service provided by the school lasts long from year to year, the quality of the school persists and tends to increase from year to year, e) Has durability (durability) which is resistant to all challenges or problems, for example, despite the monetary crisis, schools still survive (provide good service), f) Beautiful (aesthetic), for example the exterior and interior of the 
school are arranged attractively, the teacher makes educational media or interesting teaching aids, g) Human interface (personal interface) that is upholding moral values and professionalism. For example, school citizens respect each other, democracy, and respect professionalism, h) Easy to use: means school rules relating to the requirements for borrowing school facilities such as library books that are easy to apply, i) Having a special feature means having certain advantages such as superior schools in terms of mastering information technology (ICT), j) Having certain standards (conformance to specification) means that they have met certain standards such as minimum service standards, $\mathrm{k}$ ) Having the element of accuracy (acuracy) means the accuracy in providing services such as schools are able to provide services in accordance with what the school customers want, 1) Having uniformity without variation, there is no discrimination, for example in the imple mentation of rules and sanctions or punishments, $\mathrm{m}$ ) Having the ability to serve (serviceability) is able to provide excellent service. For example, schools provide suggestion boxes and suggestions that are able to be fulfilled properly so that customers feel satisfied.Furthermore, in the EFA Global Monitoring Report (2005) or the Global Education Monitoring Report for All, it was argued that there are five dimensions of education quality which include: learner characteristics, enabling input that includes human resources and physical resources, teaching-learning process (teaching and learning), learning outcomesin accordance with expectations, (Daniel Goleman in Suparlan, 2004: 39).

\section{Obstacles in Improving the Quality of Education}

There are some obstacles faced by goverment to improve the quality of education, including:

a) Development strategies in the field of education have been more input oriented. Such a strategy relies more on the assumption that if all educational inputs have been fulfilled, such as the provision of books (teaching materials) and other learning tools, provision of educational facilities, training of teachers and other education personnel, automatically educational institutions (schools) will be able to produce quality output as expected.

b) Education management has been more macro-oriented Governed by the ranks of the bureaucracy at the central level.As a result, many factors projected at the macro (central) level do not occur or do not work as they should at the micro (school) level. In other words, it can be said that the complexity of the scope of the problem of education, often cannot be fully and accurately thought of by the central bureaucracy. c) The implementation of education is not efficient and effective

In education activities should be directed to the implementation of education that is effective and on target. The fact is that many occur in schools implementing education only as a mere formality, in schools there are some teachers who come to school only give assignments or notes after leaving the class without any explanation from the lesson and when the bell reads the new teacher returns to class just to collect as signments .

d) Less developed educational innovations

So far education has only focused on problems similar to solutions that are repeated again in the old way without improvement with the latest innovations and creative ideas. For example, the problem with the book of school packages is always repeated every year, we are trapped in the mechanism of instant profit from a handful of business people. Until the student book that is used next year cannot be passed on to the youngerstudents.

e) Low quality of physical facilities

There are many schools and colleges that have damaged buildings, ownership and use of learning media is low, library books are not complete. While the laboratory is not standard, the use of information technology is inadequate and so on. Even there are still many schools that do not have their own buildings, do not have a library, do not have a laboratory and so on.

f) Low teacher quality

The situation of teachers in Indonesia is also very concerning. Most teachers do not have sufficient professionalism to carry out their duties as mentioned in Article 39 of Law No. 20/2003, namely planning learning, carrying out learning, assessing learning outcomes, mentoring, conducting training, conducting research and community service.

g) Lack of equitable education opportunities

Opportunities to get education are still limited to elementary school level. Meanwhile early childhood education services are still very limited. Coaching failure at an early age will certainly hamper the development of human resources as a whole.

\section{RESEARCH METHOD}

This studyused a descriptive research that aims to describe a phenomenon that occurs and not to prove a hypothesis. This study applies mixed method, library method and field study that was conducted from April to Juni 2017. The writer used eight national education standards in accordance with Government Regulation Nu mber 32, 2013 namely graduate competency standards, 
content standards, process standards, educators and education personnelstandards, facilities and infrastructure standards, management standards, financing standards, and educational assessment standards as a guide to gathering information from respondents. These standards were made reference to get information by interviewingseveral principals and teachers from elementary to high school level regarding with the quality of education in North Tapanuli regency.

\section{RESULT AND DISCUSSION}

\subsection{The Overview of Education Quality in North Tapanuli Regency}

Eight indicators of national education standards were used as parameters to get an overview of quality of education in North Tapanuli regency. It has not shown significant changes of graduate competencyafter the implementation of the 2013 Curriculum. The quality of graduates has not yet been maximized. For example, there are still many high school graduates who do not have the skills or life skills that can support them especially when they do not continue their education to the college level. As a result they cannot compete in the world of work. Attitude is not as expected. The problem of students skipping learning, smoking, speeding in the city, gambling online at computer rentals, must be an important note for every educational institution, government, and parents in North Tapanuli regency. Furthermore, the development of the theme of local content learning (Crafts and Entrepreneurship) designed and chosen by education units does not seem to accommodate maximum factual needs and is less oriented to the potential of the region. Actually there are many local lesson themes based on regional potential that can be developed by schools or educational institutions such as: ulos weaving, sihobuk bean processing, or also making guitars in accordance with the North Tapanuli regency characteristics, as well as being able to equip students to be independent.Learning process based on 2013 curriculumoriented to the scientific approach for example by applying Project Based Learning (PBL) learning methods, Problem Based Learning (PBL), Discovery Learning, or Cooperative Learning. In fact, not all schools are able to implement these methods or approaches, especially schools in the sub-district of North Tapanuli. They still applies conventional learning models (teacher oriented).Based on the observations of the authors in the field, it may be said that not all teachers in North Tapanuli regency fully master the basic substance of the 2013 Curriculum. Whereas, it is important so that they can work professionally in carrying out their duties.There are still a number of schools in North Tapanuli regency that have not met the standard of facilities and infrastructure. For example the limitations of the study room, workshops, laboratories and facilities, library, and computer units. There is still a polemic in the management of education, for example regarding the management of educational assistance from the government which should not be assigned to the principal, because the principal does not have the competence to the task. In addition, aspects of supervision or controlling are still weak.In terms of the funding budget in schools, until now the polemic found was the difficulty for principals in planning a one-year official trip financing, this was due to the urgency of work meetings. Included in this case is the polemic about the transportation costs of the National Examiners in schools that are located very far from the city center.After the implementation of 2013 curriculum based assessment, in practice there is still a dualis $\mathrm{m}$ among teachers. The components of the assessment are in accordance with the format of the 2013 results of the curriculum learning report, there are still some teachers who still do not understand it.

\subsection{The Efforts to improve the quality of education}

1) Improvement on Teacher's Professional Competence A professional teacher does not only teach but also educates, guides, directs, trains, assesses, and evaluates students. They must have four competencies including 1) Pedagogic competence: ability to manage learning: understanding the foundation of education and participants, being able to develop curriculum, and designing learning, 2) personality competence: faithful, wise, wise, authoritative, honest, democrat ic, and an example for students, 3) social competence: able to communicate well or in society, and 4) professional competence: mastering the field taught.

2) Improvement on Education Facilities and Infrastructure Educational facilities are one of the educational factors that are deliberately held and used for the achievement of educational goals. Definition of educational tools and facilities as a tool factor, distribution, and use of each in the implementation of education.

3) Strengthen on SchoolBased Management (SBM) and Total Quality Management

The implementation of School Based Management is able to improve the quality of education through the independence of schools and school initiatives in empowering all available resources, increasing the responsibility and concern of the school community towards the implementation of education, this is because all school communities are involved in decision making. SBM is also able to increase healthy competition between schools, because schools will try 
to improve their respective education to be superior to other schools (Nurkolis, 2003: 27).

There are several strategies that are expected through the implementation of School Based Management (SBM), namely:

(1) One strategy is to create conducive conditions to be able to implement School Based Management, namely increasing the capacity and commitment of all school members, including the community and parents of students. Efforts to strengthen the role of the principal must be the policy that accompanies the implementation of the School Based Management policy. For example, there is transparency by displaying the School Revenue and Expenditure Budget Plan on the school notice board and making incidental reports in the form of booklets, leaflets, or posters about the planned school activities. What's more if the school principal and school committee chairman can appear together in the announcement media.

(2) The central government emphasizes its role in the implementation of monitoring and evaluation. In other words, the central government and local govern ments need to carry out joint activities in order to monitor and evaluate the implementation of School Based Managementin schools.

(3) Develop a model of school empowerment program, not just doing School Based Managementtraining, which is more fulfilled by providing information to schools. The school empowerment model in the form of mentoring or facilitation is considered to provide more tangible results compared to the old patterns of upgradingSchool Based Management.Improving the quality of education on its implementation requires intensive supervision. Implementation of roles and supervisory duties in schools can actually be positioned in quality assurance efforts that are matched by qualitity enhancement. Quality assurance is related to the superstructure initiative of the school organization or the principal and the approach is top down, while the quality enhancement is related to empowering school organization members to be able to take the initiative in improving the quality of education both in terms of increasing individual competencies and organizational capabilities through their own initiatives so that the approach is bottom up. With the implementation of School-Based Management and Integrated Quality Management, it is expected to optimally improve the quality of education in North Tapanuli regency.

d) Revitalization of School Cooperation with the Community
The education process does not only run in school but also outside school or family and community, and vice versa. Ki Hajar Dewantara called it the term "Tri Education Center", namely family, school and community. Therefore, between the school and parents it is necessary to establish a cooperation so that the educational process can run optimally. Not only that, this cooperation also needs to be established between the school and the business community and other educational institutions (Law Number 20 of 2003 concerning National Education System).

e) Maximizing Monitoring of the Implementation of Education

No matter how good the planning and implementation of education is, but if it is not accompanied by intensive supervision, it certainly does not provide optimal results. By intensifying monitoring of every education in all schools, and related units, it is certainly expected to improve the quality of education in North Tapanuli regency.

\section{CONCLUSION}

There are still some obstacles in improving the quality of education, namely: 1) Development strategies in the field of education have been more input oriented, 2) Management of education has been more macro-oriented, 3) The implementation of education is not efficient and effective, 4) Unqualified standardization is always changing, 5) Lesser of educational innovations, 6) Low of quality of facilities, 7) Low of quality of teachers, 8) Lack of equitable education opportunities.

Based on the result of the study, it can be concluded that the quality of education in North Tapanuli regency is still not optimal in accordance with expectations, in terms of aspects of national education standards that have become provisions. Therefore, improvements are still needed in each area of the standard. There are several efforts that can be done by education stakeholders to improve the quality of education in North Tapanuli regency, namely: 1) Improvementon teacher professional competence, 2) Improvementon education facilities and infrastructure, 3) Strengthen on School-Based Management (SBM) and Total Quality Management (TQM), 4 ) Revitalization on school collaboration with the community, and 5) Maximizing on monitoring of education implementation.

\section{REFERENCES}

[1] Hadis,Abdul dan Nurhayati. (2010).Manajemen Mutu Pendidikan.Bandung: Alfabeta.

[2] Kementerian Pendidikan dan Kebudayaan. (2015).Rencana Strategis Kementerian Pendidikan dan Kebudayaan 2015-2019. 
[3] Nurkolis. (2003). Peran Manajemen Berbasis Sekolah. Bandung: Armico.

[4] Pananrangi. Andi Rasyid. (2017).Manajemen Pendidikan. Makassar: Celebes Media Perkasa.

[5] Panjaitan, Ade Putra dkk.(2014).Korelasi Kebudayaan \& Pendidikan; Membangun Pendidikan Berbasis Budaya Lokal.Jakarta: Pustaka Obor Indonesia.

[6] Peraturan Pemerintah Nomor 13 Tahun 2015 Tentang Perubahan Kedua Atas Peraturan Pemerintah Nomor 19 Tahun 2005 Tentang Standar Nasional Pendidikan.

[7] Peraturan Pemerintah Nomor 74 Tahun 2008 Tentang Guru.

[8] Permendiknas Nomor 24 Tahun 2007 Tentang Standar Sarana dan Prasarana.

[9] Rencana Strategis Kementerian Pendidikan dan Kebudayaan 2015-2019

[10] Sudaradjat. (2005).Manajemen Peningkatan Mutu Berbasis Sekolah. Bandung: Cipta Grafika.

[11] Suparlan. (2004). Mencerdaskan Kehidupan Bangsa, Dari Konsepsi Sampai Dengan Implementasi. Yogyakarta: Hikayat.

[12] Syaodih,Nana.(2006).Pengendalian Mutu Pendidikan Sekolah Menengah.Bandung: Penerbit Refika Aditama.

[13] Tilaar.HAR.(2006).Standarisasi Pendidikan Nasional: Suatu Tinjauan Kristis. Jakarta: Rineka Cipta.

[14] Undang-Undang Nomor 20 Tahun 2003 Tentang Sistem Pendidikan Nasional.

[15] Undang-Undang Nomor 17 Tahun 2007 Tentang Rencana Pembangunan Jangka Panjang Nasional.

[16] Usman.(2006). Manajemen Teori, Praktek dan Riset Pendidikan. Jakarta: Bumi Aksara. 